\title{
Facile synthesis of mono-, bis- and tris-aryl-substituted aniline derivatives in aqueous DMF
}

\author{
Chun Liu,* Xiaoxiao Song, Qijian Ni, and Jieshan Qiu \\ State Key Lab of Fine Chemicals, Dalian University of Technology, Dalian 116024, P R China \\ E-mail: chunliu70@yahoo.com
}

\begin{abstract}
A facile, efficient and general protocol for synthesizing a series of mono-, bis- and tris-arylsubstituted aniline derivatives is described via the $\mathrm{Pd}(\mathrm{OAc})_{2}$-catalyzed aerobic and ligand-free Suzuki reaction of mono-, di- and tribromoanilines with aryl boronic acids in aqueous $N, N$ dimethylformamide (DMF). This is the first example to prepare 2,6-bisaryl-4-nitroanilines and 2,6-bisarylanilines via a palladium-catalyzed ligand-free Suzuki reaction.
\end{abstract}

Keywords: aryl-substituted aniline; Suzuki reaction; palladium; ligand-free; aqueous

\section{Introduction}

Mono-, bis- and tris-aryl-substituted aniline derivatives have been extensively used in the synthesis of dyes, pharmaceuticals, ferromagnetic materials, and especially organometallic complexes, ${ }^{1-4}$ because the amino group can react easily with aldehydes or ketones to afford the products with strong electronic donor properties and versatile structures, which have excellent coordinative ability to metals after further modification. Over the past decade, complexes synthesized from aniline derivatives have been a focus in organometallic chemistry and catalysis, such as $N$-heterocyclic carbene ligands (NHC) and $\beta$-diketiminate (nacnac) ligands. ${ }^{5-10}$

So far, several approaches to the construction of mono-, bis- and tris-aryl-substituted aniline derivatives have been developed, such as nitration followed by reduction, ${ }^{11-12}$ or via the palladium-catalyzed Suzuki reaction promoted by an oxygen and/or moisture sensitive ligand. ${ }^{13-}$ ${ }^{18}$ In 1995, Miura et al. reported $\mathrm{Pd}\left(\mathrm{PPh}_{3}\right)_{4}$ as catalyst for the Suzuki reaction to synthesize mono-, di-, and triphenylanilines. ${ }^{13}$ Later, Paul et al. demonstrated a silica supported ligand-free palladium catalyst for the Suzuki reaction to provide 2,4,6-triphenylaniline. ${ }^{15}$ In 2004, Zuideveld et al. described a protocol to afford 2,6-bisarylanilines via the $\operatorname{Pd}\left(\mathrm{PPh}_{3}\right)_{4}$-catalyzed Suzuki reaction in toluene/ethanol $/ \mathrm{H}_{2} \mathrm{O}{ }^{6}{ }^{6}$ Meinhard et al. in 2007 reported a method to prepare 2,6bisarylanilines using $\mathrm{Pd}\left(\mathrm{PPh}_{3}\right)_{4}$ in benzene. ${ }^{4}$ Pisano reported the preparation of 2,6diphenylaniline product with $\mathrm{Pd}\left(\mathrm{PPh}_{3}\right)_{4}$ in refluxing DME under $\mathrm{N}_{2}$ to obtain $81 \%$ yield in 2 h. ${ }^{18}$ 
In 2010, Frech et al. presented the preparation of 2,4,6-triphenylaniline in a Pd-pincer complex mediated system. ${ }^{17}$ However, these methods are always combined with complex ligands, high palladium loadings, long reaction times, harsh conditions or low yields.

In recent years, many protocols have been developed to synthesize 4-arylanilines via the palladium-catalyzed Suzuki reaction either in the presence of a ligand or under ligand-free conditions. ${ }^{19-21}$ In 2004, Thiot et al. prepared ionic gel-stabilized palladium nanoparticles to catalyze the cross-coupling of 4-bromoaniline with phenyl boronic acid in $\mathrm{MeCN} / \mathrm{H}_{2} \mathrm{O}$ at $85^{\circ} \mathrm{C}$ for $6.5 \mathrm{~h}$ under argon. ${ }^{19}$ In 2010, Singh et al. reported the same reaction in aqueous DMF at $110^{\circ} \mathrm{C}^{20}$ Zhang described a ligand-free protocol in 2005 to afford 4-phenylaniline in $\mathrm{PEG} / \mathrm{H}_{2} \mathrm{O}$ at the presence of $1 \mathrm{~mol} \% \mathrm{Pd}(\mathrm{OAc})_{2}$ at $50^{\circ} \mathrm{C}^{21}$ However, a general and facile protocol for the palladium-catalyzed ligand-free Suzuki reaction for synthesizing mono-, bis- and tris-arylsubstituted aniline derivatives has not been reported.

The palladium-catalyzed Suzuki coupling reaction has been extensively used in the synthesis of herbicides, natural products, advanced materials, and pharmaceuticals. ${ }^{22-30}$ Recently, this transformation has been performed successfully without any additional ligand under mild conditions. ${ }^{31-37}$ For example, systems of $10 \% \mathrm{Pd} / \mathrm{C}-i-\mathrm{PrOH},{ }^{31} \mathrm{Pd}(\mathrm{OAc})_{2}$-ethylene glycol monomethyl ether $/ \mathrm{H}_{2} \mathrm{O}^{32}$ and $\mathrm{Pd}(\mathrm{OAc})_{2}$-acetone $/ \mathrm{H}_{2} \mathrm{O}^{33}$ have been developed. For the past few years, we have been involved in the development of the palladium-catalyzed ligand-free Suzuki reaction and have reported several effective ligand-free protocols, such as $\mathrm{Pd}(\mathrm{OAc})_{2}-i$ $\mathrm{PrOH} / \mathrm{H}_{2} \mathrm{O}^{34}, \mathrm{Pd}(\mathrm{OAc})_{2}-\mathrm{PEG} 400^{35,36}$ and $\mathrm{PdCl}_{2}-\mathrm{DMF} / \mathrm{H}_{2} \mathrm{O}^{37}$, which could perform the Suzuki reaction efficiently under aerobic and mild conditions. In the present paper, we report a facile and general approach for the synthesis of mono-, bis- and tris-aryl-substituted aniline derivatives via the $\mathrm{Pd}(\mathrm{OAc})_{2}$-catalyzed aerobic and ligand-free Suzuki reaction of mono-, di- and tribromoanilines with aryl boronic acids in aqueous DMF.

\section{Results and Discussion}

\section{Investigation of reaction conditions}

In our concept, solvents play a crucial role in the palladium-catalyzed ligand-free Suzuki reaction. Thus, we first studied the effects of different solvents on the model cross-coupling of 2,4,6tribromoaniline with phenyl boronic acid under air at $80^{\circ} \mathrm{C}$. The results are shown in Table 1 (Table 1, entries 1-5). We tested a series of typical solvents which were commonly used in the palladium-catalyzed ligand-free Suzuki reaction. To our surprise, PEG400 exhibited a rather poor catalytic activity under the reaction conditions (Table 1, entry 1), although the $\mathrm{Pd}(\mathrm{OAc})_{2} / \mathrm{PEG} 400$ catalytic system could catalyze the Suzuki coupling of aryl chlorides efficiently at room temperature. ${ }^{35,36}$ However, reactions carried out in aqueous media demonstrated high efficiency. For example, the reaction could finish in $i-\mathrm{PrOH} / \mathrm{H}_{2} \mathrm{O}$ in $60 \mathrm{~min}$ (Table 1, entry 2), and a quantitative yield of 2,4,6-triphenylaniline was obtained in $\mathrm{DMF} / \mathrm{H}_{2} \mathrm{O}$ 
within 30 min (Table 1, entry 4). The results revealed that $\mathrm{DMF} / \mathrm{H}_{2} \mathrm{O}(2 / 1)$ was the preferred solvent to activate this catalytic system.

The next investigation was to optimize the palladium species. As shown in Table 1, the reaction catalyzed by $\mathrm{Pd}(\mathrm{OAc})_{2}$ resulted in a quantitative yield in $30 \mathrm{~min}$ (Table 1, entry 4), while only $2 \%$ and $5 \%$ yields were obtained using $\mathrm{Pd}_{2}(\mathrm{dba})_{3}$ and $5 \% \mathrm{Pd} / \mathrm{C}$, respectively (Table 1 , entries 7 and 8). This was consistent with our reported results. ${ }^{37-39}$ Hence, $\mathrm{Pd}(\mathrm{OAc})_{2}$ is the best choice.

Table 1. Effects of solvents and palladium species on the Suzuki reaction of 2,4,6tribromoaniline with phenyl boronic acid ${ }^{\mathrm{a}}$

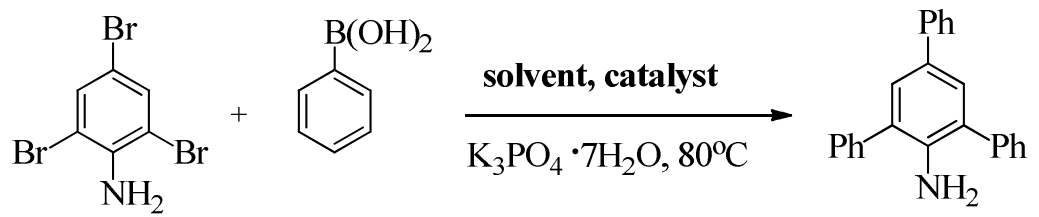

\begin{tabular}{lllll}
\hline Entry & Solvent $(\mathrm{V} / \mathrm{V})$ & Catalyst $(\mathrm{mol} \%)$ & Time $/ \mathrm{min}$ & ${\text { Yield } / \%^{\mathrm{b}}}^{\mathrm{a}}$ \\
\hline 1 & $\mathrm{PEG} 400$ & $\mathrm{Pd}(\mathrm{OAc})_{2}(1.0)$ & 60 & $10^{\mathrm{c}}$ \\
2 & $i$-PrOH$/ \mathrm{H}_{2} \mathrm{O}(2 / 1)$ & $\mathrm{Pd}(\mathrm{OAc})_{2}(1.0)$ & 60 & 97 \\
3 & $\mathrm{DMF} / \mathrm{H}_{2} \mathrm{O}(3 / 1)$ & $\mathrm{Pd}(\mathrm{OAc})_{2}(1.0)$ & 60 & 86 \\
4 & $\mathrm{DMF} / \mathrm{H}_{2} \mathrm{O}(\mathbf{2} / \mathbf{1})$ & $\mathrm{Pd}(\mathrm{OAc})_{2}(\mathbf{1 . 0})$ & $\mathbf{3 0}$ & $\mathbf{9 9}$ \\
5 & $\mathrm{DMF} / \mathrm{H}_{2} \mathrm{O}(1 / 1)$ & $\mathrm{Pd}(\mathrm{OAc})_{2}(1.0)$ & 60 & 75 \\
6 & $\mathrm{DMF} / \mathrm{H}_{2} \mathrm{O}(2 / 1)$ & $\mathrm{PdCl}_{2}(1.0)$ & 60 & $91^{\mathrm{c}}$ \\
7 & $\mathrm{DMF} / \mathrm{H}_{2} \mathrm{O}(2 / 1)$ & $\mathrm{Pd}_{2}(\mathrm{dba})_{3}(1.0)$ & 60 & $2^{\mathrm{c}}$ \\
8 & $\mathrm{DMF} / \mathrm{H}_{2} \mathrm{O}(2 / 1)$ & $5 \% \mathrm{Pd} / \mathrm{C}(1.0)$ & 60 & $5^{\mathrm{c}}$ \\
\hline
\end{tabular}

${ }^{a}$ Reaction conditions: 2,4,6-tribromoaniline $(0.25 \mathrm{mmol})$, phenyl boronic acid (1.125 mmol), $\mathrm{K}_{3} \mathrm{PO}_{4} \cdot 7 \mathrm{H}_{2} \mathrm{O}(1.25 \mathrm{mmol})$, solvent $(4 \mathrm{~mL}), 80{ }^{\circ} \mathrm{C}$, in air. The reaction was monitored by TLC. ${ }^{\mathrm{b}}$ Isolated yields. ${ }^{\mathrm{c}}$ HPLC yield.

Further investigation was carried out to study the influences of the bases. The results are summarized in Table 2. $\mathrm{K}_{3} \mathrm{PO}_{4} \cdot 7 \mathrm{H}_{2} \mathrm{O}, \mathrm{K}_{2} \mathrm{CO}_{3}$ and $\mathrm{Na}_{2} \mathrm{CO}_{3}$ exhibited high reactivity, and $\mathrm{K}_{3} \mathrm{PO}_{4} \cdot 7 \mathrm{H}_{2} \mathrm{O}$ was the best one in terms of rate (Table 2, entries 4, 5 and 7). Some other inorganic bases, such as $\mathrm{KOH}, \mathrm{LiOH} \cdot \mathrm{H}_{2} \mathrm{O}$ also gave good yields (Table 2, entries 2 and 3). $\mathrm{NaOH}, \mathrm{Li}_{2} \mathrm{CO}_{3}$ and $\mathrm{KF}$ resulted in moderate yields (Table 2, entries 1, 6 and 8). While the organic bases such as $\mathrm{CH}_{3} \mathrm{COONa}$ and $\mathrm{CH}_{3} \mathrm{ONa}$ provided relatively low reactivity (Table 2, entries 9 and 10). The results demonstrated that $\mathrm{K}_{3} \mathrm{PO}_{4} \cdot 7 \mathrm{H}_{2} \mathrm{O}$ was the optimum base. Temperature was the last factor which was investigated. From Table 2, it is clear that the higher the temperature was, the better the result was obtained. Therefore, $80^{\circ} \mathrm{C}$ is the optimal temperature (Table 2, entry 7 ).

Table 2. Effects of bases and temperature on the Suzuki reaction of 2,4,6-tribromoaniline with phenyl boronic acid ${ }^{\mathrm{a}}$ 


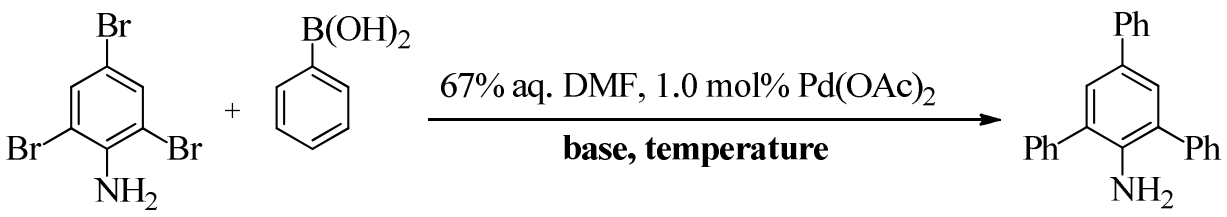

\begin{tabular}{lllll}
\hline Entry & Base & Temperature $/{ }^{\circ} \mathrm{C}$ & Time $/$ min & Yield $/ \%^{\mathrm{b}}$ \\
\hline 1 & $\mathrm{NaOH}$ & 80 & 60 & $59^{\mathrm{c}}$ \\
2 & $\mathrm{KOH}$ & 80 & 60 & $76^{\mathrm{c}}$ \\
3 & $\mathrm{LiOH} \cdot \mathrm{H}_{2} \mathrm{O}$ & 80 & 60 & $88^{\mathrm{c}}$ \\
4 & $\mathrm{~K}_{2} \mathrm{CO}_{3}$ & 80 & 60 & 99 \\
5 & $\mathrm{Na}_{2} \mathrm{CO}_{3}$ & 80 & 60 & $99^{\mathrm{c}}$ \\
6 & $\mathrm{Li}_{2} \mathrm{CO}_{3}$ & 80 & 60 & $48^{\mathrm{c}}$ \\
7 & $\mathrm{~K}_{3} \mathbf{P O}_{4} \cdot 7 \mathrm{H}_{2} \mathrm{O}$ & $\mathbf{8 0}$ & $\mathbf{3 0}$ & $\mathbf{9 9}$ \\
8 & $\mathrm{KF}$ & 80 & 60 & $61^{\mathrm{c}}$ \\
9 & $\mathrm{CH}_{3} \mathrm{COONa}$ & 80 & 60 & $9^{\mathrm{c}}$ \\
10 & $\mathrm{CH}_{3} \mathrm{ONa}$ & 80 & 60 & $36^{\mathrm{c}}$ \\
11 & $\mathrm{~K}_{3} \mathrm{PO}_{4} \cdot 7 \mathrm{H}_{2} \mathrm{O}$ & 50 & 60 & $64^{\mathrm{c}}$ \\
12 & $\mathrm{~K}_{3} \mathrm{PO}_{4} \cdot 7 \mathrm{H}_{2} \mathrm{O}$ & 60 & 60 & $87^{\mathrm{c}}$ \\
13 & $\mathrm{~K}_{3} \mathrm{PO}_{4} \cdot 7 \mathrm{H}_{2} \mathrm{O}$ & 70 & 60 & $98^{\mathrm{c}}$ \\
\hline
\end{tabular}

${ }^{a}$ Reaction conditions: 2,4,6-tribromoaniline $(0.25 \mathrm{mmol})$, phenyl boronic acid $(1.125 \mathrm{mmol})$, base $(1.25 \mathrm{mmol}), \mathrm{Pd}(\mathrm{OAc})_{2}(1.0 \mathrm{~mol} \%), \mathrm{DMF} / \mathrm{H}_{2} \mathrm{O}(2.7 \mathrm{~mL} / 1.3 \mathrm{~mL})$, in air. The reaction was monitored by TLC. ${ }^{\mathrm{b}}$ Isolated yields. ${ }^{\mathrm{c}}$ HPLC yield.

\section{Scope and limitation of substrates}

To evaluate the scope and limitations of this procedure, the cross-couplings of 2,4,6tribromoaniline with a series of aryl boronic acids were examined under optimized reaction conditions. As shown in Table 3, aryl boronic acids bearing electron-rich groups afforded good to excellent yields (Table 3, entries 2-4). To the best of our knowledge, the present method is the most effective protocol for the synthesis of such products. ${ }^{8}$ Apparently, electronic effects did not affect the yields in this methodology (Table 3, entries 5-7). 
Table 3. The Suzuki reaction of 2,4,6-tribromoaniline with aryl boronic acids ${ }^{\mathrm{a}}$

\begin{tabular}{lll} 
Entry \\
\hline
\end{tabular}

a Reaction conditions: 2,4,6-tribromoaniline (0.25 mmol), aryl boronic acid (1.125 mmol), $\mathrm{K}_{3} \mathrm{PO}_{4} \cdot 7 \mathrm{H}_{2} \mathrm{O}(1.25 \mathrm{mmol}), \mathrm{Pd}(\mathrm{OAc})_{2}(1.0 \mathrm{~mol} \%), \mathrm{DMF} / \mathrm{H}_{2} \mathrm{O}(2.7 \mathrm{~mL} / 1.3 \mathrm{~mL}), 80{ }^{\circ} \mathrm{C}$, in air. The reaction was monitored by $\mathrm{TLC}^{\mathrm{b}}{ }^{\mathrm{b}}$ Isolated yields

We further investigated the Suzuki reaction of 2,6-dibromo-4-nitroaniline with aryl boronic acids. The results are shown in Table 4. Control experiments were carried out to reveal the effect of temperature on the cross-coupling of 2,6-dibromo-4-nitroaniline with 4-methylphenyl boronic acid (Table 4, entries 1-3). Obviously, the reaction at $80^{\circ} \mathrm{C}$ was much better than those at $50^{\circ} \mathrm{C}$ and $25^{\circ} \mathrm{C}$. Aryl boronic acids bearing either electron-rich or electron-deficient groups demonstrated high reactivity and afforded the corresponding products in high yields in the presence of $0.5 \mathrm{~mol} \% \mathrm{Pd}(\mathrm{OAc})_{2}$ (Table 4, entries 3 and 5). Cross-couplings involving mono-, diand trifluorophenyl boronic acids were all completed in short reaction times (Table 4, entries 68 ). To the best of our knowledge, the present method is the first example for the synthesis of 2,6bisaryl-4-nitroanilines in the absence of a ligand. Moreover, this is the fastest and most efficient protocol compared to the reported approaches, which were associated with phosphines, harsh conditions and long reaction times. ${ }^{4}$ 
Table 4. The Suzuki reaction of 2,6-dibromo-4-nitroaniline with aryl boronic acids ${ }^{\text {a }}$

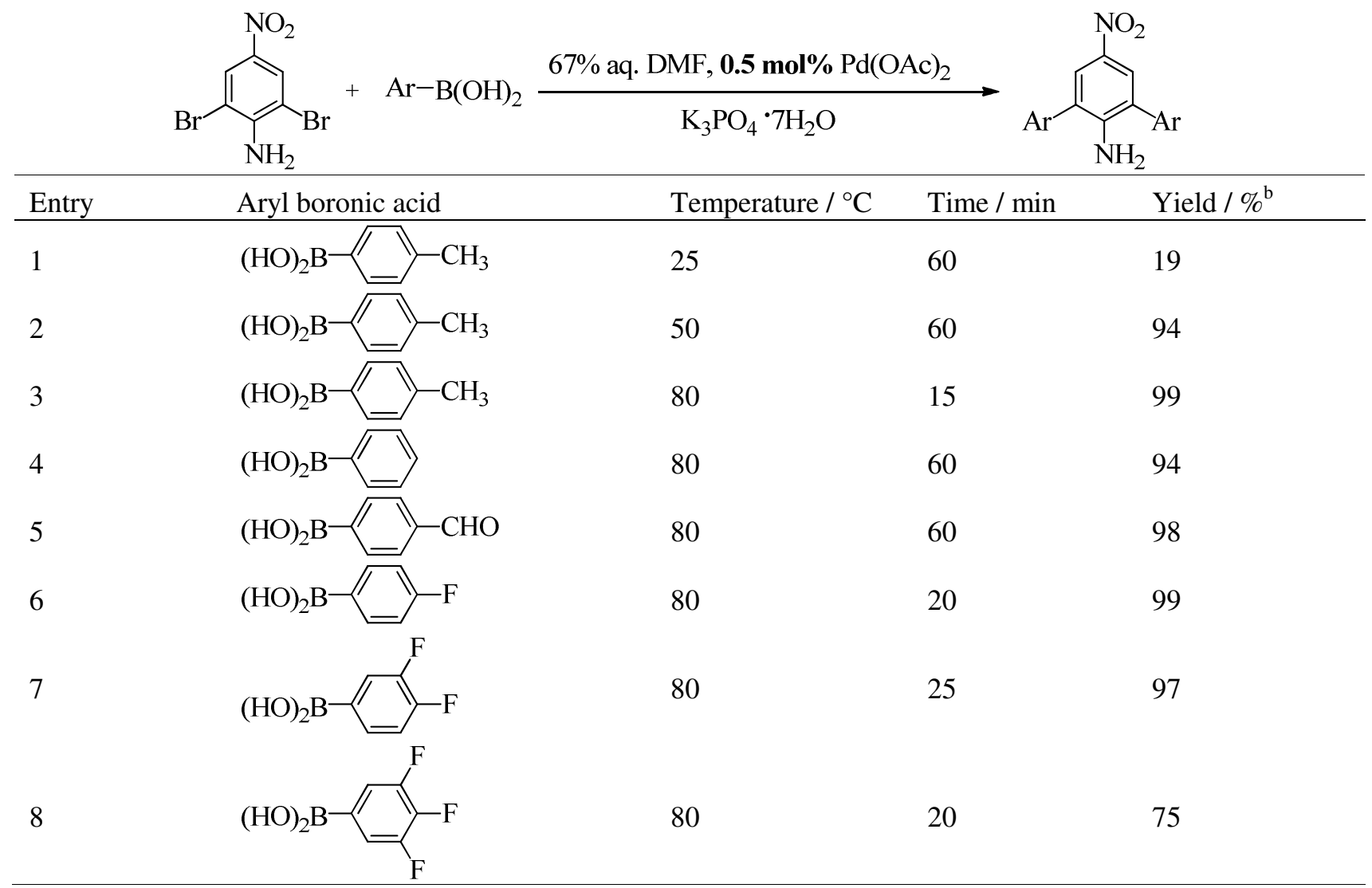

${ }^{a}$ Reaction conditions: 2,6-dibromo-4-nitroaniline $(0.25 \mathrm{mmol})$, aryl boronic acid $(0.75 \mathrm{mmol})$, $\mathrm{K}_{3} \mathrm{PO}_{4} \cdot 7 \mathrm{H}_{2} \mathrm{O}(0.75 \mathrm{mmol}), \mathrm{Pd}(\mathrm{OAc})_{2}(0.5 \mathrm{~mol} \%), \mathrm{DMF} / \mathrm{H}_{2} \mathrm{O}(2.7 \mathrm{~mL} / 1.3 \mathrm{~mL})$, in air. The reaction was monitored by $\mathrm{TLC}^{\mathrm{b}}{ }^{\mathrm{b}}$ Isolated yields.

Further investigation was carried out to study the Suzuki reaction of 2,6-dibromoaniline with aryl boronic acids (see Table 5). The results indicated that 4-methylphenyl boronic acid coupled more efficiently than 4-methoxyphenyl boronic acid, resulted in $96 \%$ and $62 \%$ yields, respectively (Table 5, entries 2 and 3). The reason why 4-methoxyl boronic acid showed much lower activity than 4-methyl boronic acid might be due to the 4-MeO's negative inductive effect, resulting in a decrease of the nucleophilicity of 4-methoxyphenyl boronic acid. As far as we know, 2,6-bisarylaniline derivatives are very important intermediates to prepare $N, N$-bidentate ligands. ${ }^{5-6}$ The present protocol is the simplest and most efficient method to construct these intermediates compared with the previous reports. ${ }^{5-6}$ To our delight, fluoro-substituted phenyl boronic acids all gave good to excellent yields (Table 5, entries 5-7). 
Table 5. The Suzuki reaction of 2, 6-dibromoaniline with aryl boronic acids ${ }^{\mathrm{a}}$

\begin{tabular}{|c|c|c|c|}
\hline Entry & Aryl boronic acid & Time / min & Yield / \% ${ }^{\mathrm{b}}$ \\
\hline 1 & $(\mathrm{HO})_{2} \mathrm{~B}-$ & 80 & 96 \\
\hline 2 & $(\mathrm{HO})_{2} \mathrm{~B}--\mathrm{CH}_{3}$ & 45 & 96 \\
\hline 3 & $(\mathrm{HO})_{2} \mathrm{~B}-$ & 60 & 62 \\
\hline 4 & $(\mathrm{HO})_{2} \mathrm{~B}^{-}$ & 120 & 66 \\
\hline 5 & $(\mathrm{HO})_{2} \mathrm{~B}^{-}$ & 60 & 96 \\
\hline 6 & $(\mathrm{HO})_{2} \mathrm{~B}^{-}$ & 65 & 96 \\
\hline 7 & $(\mathrm{HO})_{2} \mathrm{~B}-$ & 20 & 88 \\
\hline
\end{tabular}

a Reaction conditions: 2,6-dibromoaniline $(0.5 \mathrm{mmol})$, aryl boronic acid (1.5 mmol), $\mathrm{K}_{3} \mathrm{PO}_{4} \cdot 7 \mathrm{H}_{2} \mathrm{O}(1.5 \mathrm{mmol}), \mathrm{Pd}(\mathrm{OAc})_{2}(0.5 \mathrm{~mol} \%), \mathrm{DMF} / \mathrm{H}_{2} \mathrm{O}(2.7 \mathrm{~mL} / 1.3 \mathrm{~mL}), 80{ }^{\circ} \mathrm{C}$, in air. The reaction was monitored by $\mathrm{TLC}^{\mathrm{b}}{ }^{\mathrm{b}}$ Isolated yields.

To further extend the scope of this methodology, we tried to carry out the Suzuki coupling of 4-bromoaniline with a series of aryl boronic acids. As shown in Table 6, aryl boronic acids bearing electron-rich groups or ortho-substituted groups, such as 4-methyl, 2-methyl, 2-methoxyl, and mono-, di-, trifluroro groups, coupled with 4-bromoaniline resulting in excellent yields (Table 6, entries 2-4, 6-8). Compared with the results in Table 5, it was clear that the steric hindrance did not affect the yields (Table 6, entries 3 and 4). The coupling also proceeded readily with electron deficient boronic acids, e.g. 4-cyanophenylboronic acid, to afford the product in $62 \%$ yield (Table 6 , entry 5 ). Unfortunately, this protocol could not activate chlorinated anilines. 
Table 6. The Suzuki reaction of 4-bromoaniline with aryl boronic acids ${ }^{\mathrm{a}}$<smiles>Nc1ccc(Br)cc1</smiles>

\begin{tabular}{|c|c|c|c|}
\hline Entry & Aryl boronic acid & Time / min & Yield $/ \%^{\mathrm{b}}$ \\
\hline 1 & $(\mathrm{HO})_{2} \mathrm{~B}-$ & 20 & 99 \\
\hline 2 & $(\mathrm{HO})_{2} \mathrm{~B}-$ & 20 & 99 \\
\hline 3 & $(\mathrm{HO})_{2} \mathrm{~B}^{-}$ & 50 & 98 \\
\hline 4 & $(\mathrm{HO})_{2} \mathrm{~B}$ & 120 & 94 \\
\hline 5 & $(\mathrm{HO})_{2} \mathrm{~B}^{-}$ & 120 & 62 \\
\hline 6 & $(\mathrm{HO})_{2} \mathrm{~B}^{-}$ & 25 & 97 \\
\hline 7 & $(\mathrm{HO})_{2} \mathrm{~B}$ & 40 & 93 \\
\hline 8 & $(\mathrm{HO})_{2} \mathrm{~B}$ & 30 & 92 \\
\hline
\end{tabular}

${ }^{a}$ Reaction conditions: 4-bromoaniline $(0.5 \mathrm{mmol})$, aryl boronic acid $(0.75 \mathrm{mmol}), \mathrm{K}_{3} \mathrm{PO}_{4} \cdot 7 \mathrm{H}_{2} \mathrm{O}$ $(1.0 \mathrm{mmol}), \mathrm{Pd}(\mathrm{OAc})_{2}(0.5 \mathrm{~mol} \%), \mathrm{DMF} / \mathrm{H}_{2} \mathrm{O}(2.7 \mathrm{~mL} / 1.3 \mathrm{~mL}), 80{ }^{\circ} \mathrm{C}$, in air. The reaction was monitored by TLC.

${ }^{\mathrm{b}}$ Isolated yields.

\section{Conclusions}

In summary, we have developed a facile and general protocol to synthesize mono-, bis- and trisaryl-substituted aniline derivatives via the $\mathrm{Pd}(\mathrm{OAc})_{2}$-catalyzed ligand-free Suzuki reaction in 67\% aqueous DMF under air. It is noteworthy that a wide range of substrates including mono-, di- and tribromoanilines could perform the Suzuki reaction with aryl boronic acids smoothly resulting in good to excellent yields.

Further study including the synthesis and catalytic activity of NHC and nacnac ligands prepared from aryl-substituted anilines described in this paper are currently under investigation in our laboratory. 


\section{Experimental Section}

General. All the reactions were carried out under air. All aryl halides and aryl boronic acids were purchased from Alfa Aesar, Avocado and used without purification. ${ }^{1} \mathrm{H}$ NMR spectra were recorded on a Varian Inova 400 spectrometer. Chemical shifts are reported in ppm relative to TMS. Mass spectroscopy data of the products were collected on a MS-EI instrument. HPLC yields were recorded on a Waters Alliance 2695-2996-2475 High Performance Liquid Chromatography. Other products were isolated by chromatography on a short silica gel (200-300 mesh) column using petroleum ether $\left(60-90{ }^{\circ} \mathrm{C}\right)$, unless otherwise noted. Compounds described in the literature were characterised by comparison of their ${ }^{1} \mathrm{H}$ NMR spectra with reported data. The HPLC measurement was carried out using an XBridge C18 $(2.1 \times 150 \mathrm{~mm}, 5 \mu \mathrm{m})$ column. Mobile phase consisted of $\mathrm{H}_{2} \mathrm{O}$ (including $0.3 \% \mathrm{HOAc}$ and $0.3 \% \mathrm{~N}\left(\mathrm{CH}_{2} \mathrm{CH}_{3}\right)_{3}$ ) and $\mathrm{MeOH}$, the gradient elution was adopted, the volume ratio of $\mathrm{H}_{2} \mathrm{O}$ to $\mathrm{MeOH}$ was 30:70 at the beginning to 0:100 at the end, the flow rate was $0.3 \mathrm{~mL} / \mathrm{min}$. A variable wavelength $\mathrm{UV}$ detector at $246 \mathrm{~nm}$ was used. The value of time of retention was $14.2 \mathrm{~min}$.

\section{Typical experimental procedure for the Suzuki reaction of bromoanilines with aryl boronic acids}

Procedure 1. A mixture of 2,4,6-tribromoaniline $(0.25 \mathrm{mmol})$, aryl boronic acid $(1.125 \mathrm{mmol})$, $\mathrm{K}_{3} \mathrm{PO}_{4} \cdot 7 \mathrm{H}_{2} \mathrm{O}(1.25 \mathrm{mmol}), \mathrm{Pd}(\mathrm{OAc})_{2}(1.0 \mathrm{~mol} \%)$, DMF $(2.7 \mathrm{~mL})$ and distilled water $(1.3 \mathrm{~mL})$ was stirred at $80^{\circ} \mathrm{C}$ under air for the indicated time. The mixture was added to brine $(15 \mathrm{~mL})$ and extracted three times with ethyl acetate $(3 \times 15 \mathrm{~mL})$. The solvent was concentrated under vacuum and the product was isolated by chromatography on a short silica gel (200-300 mesh) column.

Procedure 2. A mixture of 2,6-dibromo-4-nitroaniline $(0.25 \mathrm{mmol})$, aryl boronic acid $(0.75$ $\mathrm{mmol}), \mathrm{K}_{3} \mathrm{PO}_{4} \cdot 7 \mathrm{H}_{2} \mathrm{O}(0.75 \mathrm{mmol}), \mathrm{Pd}(\mathrm{OAc})_{2}(0.5 \mathrm{~mol} \%)$, DMF $(2.7 \mathrm{~mL})$ and distilled water $(1.3$ $\mathrm{mL}$ ) was stirred at $80^{\circ} \mathrm{C}$ under air for the indicated time. The mixture was added to brine $(15 \mathrm{~mL})$ and extracted three times with ethyl acetate $(3 \times 15 \mathrm{~mL})$. The solvent was concentrated under vacuum and the product was isolated by chromatography on a short silica gel (200-300 mesh) column.

Procedure 3. A mixture of 2,6-dibromoaniline $(0.5 \mathrm{mmol})$, aryl boronic acid $(1.5 \mathrm{mmol})$, $\mathrm{K}_{3} \mathrm{PO}_{4} \cdot 7 \mathrm{H}_{2} \mathrm{O}(1.5 \mathrm{mmol}), \mathrm{Pd}(\mathrm{OAc})_{2}(0.5 \mathrm{~mol} \%)$, DMF $(2.7 \mathrm{~mL})$ and distilled water $(1.3 \mathrm{~mL})$ was stirred at $80^{\circ} \mathrm{C}$ under air for the indicated time. The mixture was added to brine $(15 \mathrm{~mL})$ and extracted three times with ethyl acetate $(3 \times 15 \mathrm{~mL})$. The solvent was concentrated under vacuum and the product was isolated by chromatography on a short silica gel (200-300 mesh) column.

Procedure 4. A mixture of 4-bromoaniline $(0.5 \mathrm{mmol})$, aryl boronic acid $(0.75 \mathrm{mmol})$, $\mathrm{K}_{3} \mathrm{PO}_{4} \cdot 7 \mathrm{H}_{2} \mathrm{O}(1.0 \mathrm{mmol}), \mathrm{Pd}(\mathrm{OAc})_{2}(0.5 \mathrm{~mol} \%)$, DMF $(2.7 \mathrm{~mL})$ and distilled water $(1.3 \mathrm{~mL})$ was stirred at $80^{\circ} \mathrm{C}$ under air for the indicated time. The mixture was added to brine $(15 \mathrm{~mL})$ and extracted three times with ethyl acetate $(3 \times 15 \mathrm{~mL})$. The solvent was concentrated under vacuum and the product was isolated by chromatography on a short silica gel (200-300 mesh) column. 
2,4,6-Tris(4-methylphenyl)aniline (Table 3, entry 2). Prepared by procedure 1, and purified by column chromatography using petroleum ether/EtOAc 200/1 in 86\% yield. ${ }^{1} \mathrm{H}$ NMR: $\delta$ 7.49-7.46 (m, 6H, Ph), 7.38 (s, 2H, Ph), 7.29 (d, c 8.0 Hz, 4H, Ph), 7.20 (d, J 8.0 Hz, 2H, Ph), 2.41 (s, 6H, $\left.2 \times \mathrm{CH}_{3}\right), 2.37\left(\mathrm{~s}, 3 \mathrm{H}, \mathrm{CH}_{3}\right), \mathrm{ppm} ;{ }^{13} \mathrm{C} \mathrm{NMR}: \delta 140.07(\mathrm{Ph}), 138.16(\mathrm{Ph}), 137.13(2 \times \mathrm{Ph}), 136.81$ $(2 \times \mathrm{Ph}), 136.01(\mathrm{Ph}), 131.22(\mathrm{Ph}), 129.65(4 \times \mathrm{Ph}), 129.47(2 \times \mathrm{Ph}), 129.30(4 \times \mathrm{Ph}), 128.40(2 \times \mathrm{Ph})$, $128.13(2 \times \mathrm{Ph}), 126.34(2 \times \mathrm{Ph}), 21.19\left(2 \times \mathrm{CH}_{3}\right), 21.11\left(\mathrm{CH}_{3}\right)$; $\mathrm{MS}(\mathrm{EI}) \mathrm{m} / z$ : calculated value: 363.1987, found value: $363.1990\left(\mathrm{M}^{+}\right)$; $\mathrm{mp} 113.1-114.0{ }^{\circ} \mathrm{C}$.

2,4,6-Tris(3-methylphenyl)aniline (Table 3, entry 3). Prepared by procedure 1, and purified by column chromatography using petroleum ether/EtOAc 200/1 in 98\% yield. ${ }^{1} \mathrm{H}$ NMR: $\delta$ 7.41-7.35 (m, 10H, Ph), 7.27 (t, J 7.4 Hz, 1H, Ph), 7.21-7.17 (m, 2H, Ph), 7.07 (d, J 7.2 Hz, 1H, Ph), 3.91

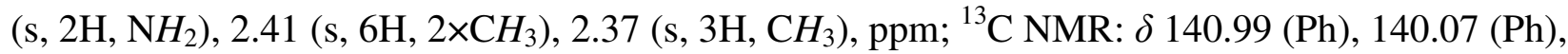
$139.77(2 \times \mathrm{Ph}), 138.70(2 \times \mathrm{Ph}), 138.31(\mathrm{Ph}), 131.39(\mathrm{Ph}), 130.22(2 \times \mathrm{Ph}), 128.94(2 \times \mathrm{Ph}), 128.75$ $(\mathrm{Ph}), 128.66(\mathrm{Ph}), 128.39(2 \times \mathrm{Ph}), 128.29(2 \times \mathrm{Ph}), 127.36(\mathrm{Ph}), 127.26(\mathrm{Ph}), 126.48(2 \times \mathrm{Ph})$, $123.67(2 \times \mathrm{Ph}), 21.70\left(\mathrm{CH}_{3}\right), 21.65\left(2 \times \mathrm{CH}_{3}\right) \mathrm{ppm}$; MS (EI) $\mathrm{m} / z$ : calculated value: 363.1987, found value: $363.1990\left(\mathrm{M}^{+}\right)$; $\mathrm{mp} 96.8-97.4{ }^{\circ} \mathrm{C}$.

2,4,6-Tris(4-methoxylphenyl)aniline (Table 3, entry 4). Prepared by procedure 1, and purified by column chromatography using petroleum ether/EtOAc 200/1 in 82\% yield. ${ }^{1} \mathrm{H}$ NMR: $\delta$ 7.527.47 (m, 6H, Ph), 7.31 (s, 2H, Ph), 7.01 (d, J $8.8 \mathrm{~Hz}, 4 \mathrm{H}, \mathrm{Ph}), 6.93$ (d, J $8.8 \mathrm{~Hz}, 2 \mathrm{H}, \mathrm{Ph}$ ), 3.87 (s, $\left.6 \mathrm{H}, 2 \times \mathrm{OCH}_{3}\right), 3.85\left(\mathrm{~s}, 2 \mathrm{H}, \mathrm{NH}_{2}\right), 3.83\left(\mathrm{~s}, 3 \mathrm{H}, \mathrm{OCH}_{3}\right), \mathrm{ppm} ;{ }^{13} \mathrm{C} \mathrm{NMR}: \delta 158.92(2 \times \mathrm{Ph}), 158.47$ $(\mathrm{Ph}), 140.19(\mathrm{Ph}), 133.68(\mathrm{Ph}), 132.02(2 \times \mathrm{Ph}), 130.81(\mathrm{Ph}), 130.49(4 \times \mathrm{Ph}), 128.00(2 \times \mathrm{Ph})$, $127.80(2 \times \mathrm{Ph}), 127.45(2 \times \mathrm{Ph}), 114.30(4 \times \mathrm{Ph}), 114.14(2 \times \mathrm{Ph}), 55.36\left(3 \times \mathrm{OCH}_{3}\right) \mathrm{ppm} ; \mathrm{MS}(\mathrm{EI})$ $\mathrm{m} / \mathrm{z}$ : calculated value: 411.1834 , found value: $411.1844\left(\mathrm{M}^{+}\right) ; \mathrm{mp} 154.0-154.8^{\circ} \mathrm{C}$.

2,4,6-Tris(4-fluorophenyl)aniline (Table 3, entry 5). Prepared by procedure 1, and purified by column chromatography using petroleum ether/EtOAc 200/1 in 93\% yield. H NMR: $\delta$ 7.53-7.49 (m, 6H, Ph), 7.30 (s, 2H, Ph), 7.17 (t, J $8.8 \mathrm{~Hz}, 4 \mathrm{H}, \mathrm{Ph}), 7.08$ (t, J 8.8 Hz, 2H, Ph), 3.81 (s, 2H, $\left.\mathrm{NH}_{2}\right), \mathrm{ppm} ;{ }^{13} \mathrm{C}$ NMR: $\delta 162.40\left(\mathrm{~d}, J_{\mathrm{CF}}=245 \mathrm{~Hz}, 2 \times \mathrm{Ph}\right), 162.15\left(\mathrm{~d}, J_{\mathrm{CF}}=244 \mathrm{~Hz}, \mathrm{Ph}\right), 140.52$ $(\mathrm{Ph}), 136.92\left(\mathrm{~d}, J_{\mathrm{CCCCF}}=3 \mathrm{~Hz}, \mathrm{Ph}\right), 135.40\left(\mathrm{~d}, J_{\mathrm{CCCCF}}=2 \mathrm{~Hz}, 2 \times \mathrm{Ph}\right), 131.15\left(\mathrm{~d}, J_{\mathrm{CCCF}}=8 \mathrm{~Hz}\right.$, $4 \times \mathrm{Ph}), 130.44(\mathrm{Ph}), 128.52(2 \times \mathrm{Ph}), 128.03\left(\mathrm{~d}, J_{\mathrm{CCCF}}=8 \mathrm{~Hz}, 2 \times \mathrm{Ph}\right), 127.57(2 \times \mathrm{Ph}), 116.08(\mathrm{~d}$, $\left.J_{\mathrm{CCF}}=21 \mathrm{~Hz}, 4 \times \mathrm{Ph}\right), 115.71\left(\mathrm{~d}, J_{\mathrm{CCF}}=21 \mathrm{~Hz}, 2 \times \mathrm{Ph}\right), \mathrm{ppm} ; \mathrm{MS}(\mathrm{EI}) \mathrm{m} / z$ : calculated value: 375.1235, found value: $375.1241\left(\mathrm{M}^{+}\right) ; \mathrm{mp} 127.6-129.4^{\circ} \mathrm{C}$.

2,4,6-Tris(3,4-difluorophenyl)aniline (Table 3, entry 6). Prepared by procedure 1, and purified by column chromatography using petroleum ether/EtOAc 200/1 in 87\% yield. ${ }^{1} \mathrm{H}$ NMR: $\delta$ 7.38$7.16(\mathrm{~m}, 11 \mathrm{H}, \mathrm{Ph}), 3.87$ (s, 2H, NH $H_{2}$, ppm; ${ }^{13} \mathrm{C} \mathrm{NMR}: \delta 150.55$ (dd, J 248, $\left.12 \mathrm{~Hz}, 3 \times \mathrm{Ph}\right), 149.96$ (dd, J 248, $12 \mathrm{~Hz}, 2 \times \mathrm{Ph}), 149.50$ (dd, J 247, $12 \mathrm{~Hz}, \mathrm{Ph}), 140.57$ (Ph), 137.48 (dd, J 6, $4 \mathrm{~Hz}, \mathrm{Ph}$ ), 135.84 (dd, J 6, $5 \mathrm{~Hz}, \mathrm{Ph}), 129.33(\mathrm{Ph}), 128.55(2 \times \mathrm{Ph}), 126.50(2 \times \mathrm{Ph}), 125.49$ (dd, J 6, $4 \mathrm{~Hz}$, $2 \times \mathrm{Ph}), 122.14(\mathrm{dd}, J$ 6, $4 \mathrm{~Hz}, 2 \times \mathrm{Ph}), 118.41$ (d, $J 17 \mathrm{~Hz}, 2 \times \mathrm{Ph}), 117.98$ (d, J $17 \mathrm{~Hz}, 2 \times \mathrm{Ph})$, 117.53 (d, J $17 \mathrm{~Hz}, \mathrm{Ph}$ ), 115.16 (d, J $18 \mathrm{~Hz}, \mathrm{Ph}$ ), ppm; MS (EI) m/z: calculated value: 429.0952, found value: $429.0955\left(\mathrm{M}^{+}\right)$; $\mathrm{mp} 194.0-194.4^{\circ} \mathrm{C}$. 
2,4,6-Tris(4-chlorophenyl)aniline (Table 3, entry 7). Prepared by procedure 1, and purified by column chromatography using petroleum ether/EtOAc 200/1 in 98\% yield. ${ }^{1} \mathrm{H}$ NMR: $\delta$ 7.50-7.44 $(\mathrm{m}, 10 \mathrm{H}, \mathrm{Ph}), 7.35(\mathrm{~d}, J 8.4 \mathrm{~Hz}, 2 \mathrm{H}, \mathrm{Ph}), 7.31(\mathrm{~s}, 2 \mathrm{H}, \mathrm{Ph}), 3.86\left(\mathrm{~s}, 2 \mathrm{H}, \mathrm{NH}_{2}\right), \mathrm{ppm} ;{ }^{13} \mathrm{C}$ NMR: $\delta$ $140.47(\mathrm{Ph}), 138.97(\mathrm{Ph}), 137.65(2 \times \mathrm{Ph}), 133.65(2 \times \mathrm{Ph}), 132.55(\mathrm{Ph}), 130.69(4 \times \mathrm{Ph}), 130.06$ $(\mathrm{Ph}), 129.25(4 \times \mathrm{Ph}), 128.90(2 \times \mathrm{Ph}), 128.36(2 \times \mathrm{Ph}), 127.58(2 \times \mathrm{Ph}), 127.27(2 \times \mathrm{Ph}), \mathrm{ppm} ; \mathrm{MS}(\mathrm{EI})$ $\mathrm{m} / \mathrm{z}$ : calculated value: 423.0348 , found value: $423.0343\left(\mathrm{M}^{+}\right)$; $\mathrm{mp} 152.0-153.1{ }^{\circ} \mathrm{C}$.

2,6-Bis(4-methylphenyl)-4-nitroaniline (Table 4, entry 3). Prepared by procedure 2, and purified by column chromatography using petroleum ether/EtOAc 40/1 in 99\% yield. ${ }^{1} \mathrm{H}$ NMR: $\delta$ 8.02 (s, 2H, Ph), 7.36 (d, J 7.6 Hz, 4H, Ph), 7.30 (d, J 8.0 Hz, 4H, Ph), 4.58 (s, 2H, NH $H_{2}$ ), 2.42 (s, $\left.6 \mathrm{H}, 2 \times \mathrm{CH}_{3}\right), \mathrm{ppm} ;{ }^{13} \mathrm{C}$ NMR: $\delta 147.68(\mathrm{Ph}), 138.65(\mathrm{Ph}), 138.23(2 \times \mathrm{Ph}), 134.39(2 \times \mathrm{Ph}), 130.03$ $(4 \times \mathrm{Ph}), 128.91(4 \times \mathrm{Ph}), 126.73(2 \times \mathrm{Ph}), 125.61(2 \times \mathrm{Ph}), 21.25\left(2 \times \mathrm{CH}_{3}\right), \mathrm{ppm} ; \mathrm{MS}(\mathrm{EI}) \mathrm{m} / \mathrm{z}:$ calculated value: 318.1368 , found value: $318.1371\left(\mathrm{M}^{+}\right)$; Melting Point: $180.2-182.1{ }^{\circ} \mathrm{C}$.

2,6-Bis(4-formylphenyl)-4-nitroaniline (Table 4, entry 5). Prepared by procedure 2, and purified by column chromatography using petroleum ether/EtOAc $20 / 1$ in $98 \%$ yield. ${ }^{1} \mathrm{H}$ NMR: $\delta$ $10.10(\mathrm{~s}, 2 \mathrm{H}, 2 \times \mathrm{CHO}), 8.11(\mathrm{~s}, 2 \mathrm{H}, \mathrm{Ph}), 8.05(\mathrm{~d}, J 8.4 \mathrm{~Hz}, 4 \mathrm{H}, \mathrm{Ph}), 7.70(\mathrm{~d}, J 8.0 \mathrm{~Hz}, 4 \mathrm{H}, \mathrm{Ph})$, 4.57 (s, $\left.2 \mathrm{H}, \mathrm{NH} H_{2}\right)$, ppm; ${ }^{13} \mathrm{C}$ NMR (100 MHz, DMSO- $\left.d_{6}, \mathrm{TMS}\right): \delta 193.29(2 \times C \mathrm{HO}), 149.42(\mathrm{Ph})$, $143.75(2 \times \mathrm{Ph}), 137.14(\mathrm{Ph}), 136.08(2 \times \mathrm{Ph}), 130.80(4 \times \mathrm{Ph}), 130.40(4 \times \mathrm{Ph}), 126.49(2 \times \mathrm{Ph})$, $125.60(2 \times \mathrm{Ph})$, ppm; MS (EI) $\mathrm{m} / z$ : calculated value: 346.0954 , found value: $346.0959\left(\mathrm{M}^{+}\right) ; \mathrm{mp}$ 226.9-228. $3^{\circ} \mathrm{C}$.

2,6-Bis(4-fluorophenyl)-4-nitroaniline (Table 4, entry 6).Prepared by procedure 2 , and purified by column chromatography using petroleum ether/EtOAc 40/1 in 99\% yield. ${ }^{1} \mathrm{H}$ NMR: $\delta$ $8.03(\mathrm{~s}, 2 \mathrm{H}, \mathrm{Ph}), 7.47-7.44(\mathrm{~m}, 4 \mathrm{H}, \mathrm{Ph}), 7.21(\mathrm{t}, J 8.6 \mathrm{~Hz}, 4 \mathrm{H}, \mathrm{Ph}), 4.47\left(\mathrm{~s}, 2 \mathrm{H}, \mathrm{NH} \mathrm{H}_{2}\right), \mathrm{ppm} ;{ }^{13} \mathrm{C}$ NMR: $\delta 162.68\left(\mathrm{~d}, J_{\mathrm{CF}}=247 \mathrm{~Hz}, 2 \times \mathrm{Ph}\right), 147.47(\mathrm{Ph}), 138.72(\mathrm{Ph}), 133.06\left(\mathrm{~d}, J_{\mathrm{CCCCF}}=3 \mathrm{~Hz}\right.$, $2 \times \mathrm{Ph}), 130.93\left(\mathrm{~d}, J_{\mathrm{CCCF}}=9 \mathrm{~Hz}, 4 \times \mathrm{Ph}\right), 125.93(2 \times \mathrm{Ph}), 125.87(2 \times \mathrm{Ph}), 116.47\left(\mathrm{~d}, J_{\mathrm{CCF}}=21 \mathrm{~Hz}\right.$, $4 \times \mathrm{Ph}$ ), ppm; MS (EI) $\mathrm{m} / \mathrm{z}$ : calculated value: 326.0867 , found value: $326.0875\left(\mathrm{M}^{+}\right)$; $\mathrm{mp} 215.9-$ $216.5^{\circ} \mathrm{C}$.

2,6-Bis(3,4-difluorophenyl)-4-nitroaniline (Table 4, entry 7). Prepared by procedure 2, and purified by column chromatography using petroleum ether/EtOAc 40/1 in 97\% yield. ${ }^{1} \mathrm{H}$ NMR: $\delta$ 8.03 (s, $2 \mathrm{H}, \mathrm{Ph}), 7.36-7.30(\mathrm{~m}, 4 \mathrm{H}, \mathrm{Ph}), 7.23-7.20(\mathrm{~m}, 2 \mathrm{H}, \mathrm{Ph}), 4.49\left(\mathrm{~s}, 2 \mathrm{H}, \mathrm{NH} \mathrm{H}_{2}\right), \mathrm{ppm} ;{ }^{13} \mathrm{C}$ NMR: $\delta 150.76(\mathrm{dd}, J 250,13 \mathrm{~Hz}, 2 \times \mathrm{Ph}), 150.45(\mathrm{dd}, J 250,13 \mathrm{~Hz}, 2 \times \mathrm{Ph}), 146.96(\mathrm{Ph}), 138.84$ $(\mathrm{Ph}), 133.72$ (dd, $J$ 7, $5 \mathrm{~Hz}, 2 \times \mathrm{Ph}), 126.16(2 \times \mathrm{Ph}), 125.49(\mathrm{dd}, J 8,3 \mathrm{~Hz}, 2 \times \mathrm{Ph}), 124.95(2 \times \mathrm{Ph})$, $118.45(2 \times \mathrm{Ph}), 118.45(\mathrm{~d}, J 34 \mathrm{~Hz}, 2 \times \mathrm{Ph})$, ppm; MS (EI) $\mathrm{m} / z$ : calculated value: 326.0678 , found value: $362.0676\left(\mathrm{M}^{+}\right) ; \mathrm{mp} 221.6-222.3{ }^{\circ} \mathrm{C}$.

2,6-Bis(3,4,5-trifluorophenyl)-4-nitroaniline (Table 4, entry 8). Prepared by procedure 2, and purified by column chromatography using petroleum ether/EtOAc 40/1 in 75\% yield. H NMR: $\delta$ 8.03 (s, 2H, Ph), 7.17-7.09 (m, 4H, Ph), 4.51 (s, $2 \mathrm{H}, \mathrm{NH}_{2}$ ), ppm; ${ }^{13} \mathrm{C}$ NMR: $\delta 151.83$ (ddd, $J 252$, $10,4 \mathrm{~Hz}, 4 \times \mathrm{Ph}), 146.56(\mathrm{Ph}), 139.96(\mathrm{dt}, J 253,15 \mathrm{~Hz}, 2 \times \mathrm{Ph}), 138.88(\mathrm{Ph}), 132.64-132.44(\mathrm{~m}$, $2 \times \mathrm{Ph}), 126.34(2 \times \mathrm{Ph}), 124.20(2 \times \mathrm{Ph}), 113.65(\mathrm{dd}, J$ 9, $6 \mathrm{~Hz}, 4 \times \mathrm{Ph}), \mathrm{ppm} ; \mathrm{MS}(\mathrm{EI}) \mathrm{m} / \mathrm{z}:$ calculated value: 398.0490 , found value: $398.0490\left(\mathrm{M}^{+}\right)$; $\mathrm{mp} 209.2-210.2^{\circ} \mathrm{C}$. 
2,6-Bis(4-methylphenyl)aniline (Table 5, entry 2). Prepared by procedure 3, and purified by column chromatography using petroleum ether/EtOAc 200/1 in 96\% yield. ${ }^{1} \mathrm{H}$ NMR: $\delta 7.33$ (dd, $J$ 48.4, 8.0 Hz, 8H, Ph), 7.10 (d, J 7.6 Hz, 2H, Ph), 6.86 (t, J 7.6 Hz, 1H, Ph), 3.85 (s, 2H, NH $H_{2}$, $2.40\left(\mathrm{~s}, 6 \mathrm{H}, 2 \times \mathrm{CH}_{3}\right), \mathrm{ppm} ;{ }^{13} \mathrm{C}$ NMR: $\delta 141.01(\mathrm{Ph}), 136.95(2 \times \mathrm{Ph}), 136.92(2 \times \mathrm{Ph}), 129.68$ $(2 \times \mathrm{Ph}), 129.60(4 \times \mathrm{Ph}), 129.28(4 \times \mathrm{Ph}), 127.95(\mathrm{Ph}), 118.18(2 \times \mathrm{Ph}), 21.29\left(2 \times \mathrm{CH}_{3}\right), \mathrm{ppm} ; \mathrm{MS}$ (EI) $m / z$ : calculated value: 273.1517 , found value: $273.1510\left(\mathbf{M}^{+}\right) ; \mathrm{mp} 118.2-119.1{ }^{\circ} \mathrm{C}$.

2,6-Bis(4-fluorophenyl)aniline (Table 5, entry 5). Prepared by procedure 3, and purified by column chromatography using petroleum ether/EtOAc 200/1 in 96\% yield.

${ }^{1} \mathrm{H}$ NMR: $\delta$ 7.48-7.45 (m, 4H, Ph), 7.17-7.12 (m, 4H, Ph), 7.09 (d, J 7.6 Hz, 2H, Ph), 6.87 (t, $J$ $7.6 \mathrm{~Hz}, 1 \mathrm{H}, \mathrm{Ph}), 3.75$ (s, 2H, NH$H_{2}$, ppm, ${ }^{13} \mathrm{C} \mathrm{NMR:} \delta 162.16\left(\mathrm{~d}, J_{\mathrm{CF}}=245 \mathrm{~Hz}, 2 \times \mathrm{Ph}\right), 140.93$ $(\mathrm{Ph}), 135.50\left(\mathrm{~d}, J_{\mathrm{CCCCF}}=3 \mathrm{~Hz}, 2 \times \mathrm{Ph}\right), 131.01\left(\mathrm{~d}, J_{\mathrm{CCCF}}=8 \mathrm{~Hz}, 4 \times \mathrm{Ph}\right), 129.95(2 \times \mathrm{Ph}), 127.03$ $(\mathrm{Ph}), 118.30(2 \times \mathrm{Ph}), 115.84\left(\mathrm{~d}, J_{\mathrm{CCF}}=21 \mathrm{~Hz}, 4 \times \mathrm{Ph}\right), \mathrm{ppm} ; \mathrm{MS}(\mathrm{EI}) \mathrm{m} / \mathrm{z}$ : calculated value: 281.1016, found value: $281.1018\left(\mathrm{M}^{+}\right)$; $\mathrm{mp} 146.0-147.6{ }^{\circ} \mathrm{C}$.

2,6-Bis(3,4-difluorophenyl)aniline (Table 5, entry 6). Prepared by procedure 3, and purified by column chromatography using petroleum ether/EtOAc 200/1 in 96\% yield. ${ }^{1} \mathrm{H}$ NMR: $\delta$ 7.33-7.29 (m, 2H, Ph), 7.27-7.19 (m, 4H, Ph), 7.08 (d, J 7.6 Hz, 2H, Ph), 6.87 (t, J 7.6 Hz, 1H, Ph), 3.77 (s, 2H, NH$H_{2}$ ), ppm, ${ }^{13} \mathrm{C}$ NMR: $\delta 150.46$ (dd, $\left.J 248,12 \mathrm{~Hz}, 2 \times \mathrm{Ph}\right), 149.77$ (dd, $J 248,12 \mathrm{~Hz}, 2 \times \mathrm{Ph}$ ), $140.64(\mathrm{Ph}), 136.28$ (dd, J 6, $4 \mathrm{~Hz}, 2 \times \mathrm{Ph}), 130.19(\mathrm{Ph}), 126.06(\mathrm{Ph}), 125.47$ (dd, J 6, $4 \mathrm{~Hz}, 2 \times \mathrm{Ph})$, $118.45(2 \times \mathrm{Ph}), 118.37(\mathrm{~d}, J 17 \mathrm{~Hz}, 2 \times \mathrm{Ph}), 117.78(\mathrm{~d}, J 17 \mathrm{~Hz}, 2 \times \mathrm{Ph}) \mathrm{ppm}$; MS (EI) $m / z$ : calculated value: 317.0828 , found value: $317.0818\left(\mathrm{M}^{+}\right)$; $\mathrm{mp} 88.2-89.0{ }^{\circ} \mathrm{C}$.

2,6-Bis(3,4,5-trifluorophenyl)aniline (Table 5, entry 7). Prepared by procedure 3, and purified by column chromatography using petroleum ether/EtOAc $200 / 1$ in $88 \%$ yield. ${ }^{1} \mathrm{H}$ NMR: $\delta$ 7.16$7.07(\mathrm{~m}, 6 \mathrm{H}, \mathrm{Ph}), 6.87(\mathrm{t}, J 7.6 \mathrm{~Hz}, 1 \mathrm{H}, \mathrm{Ph}), 3.78$ (s, 2H, NH$H_{2}$, ppm, ${ }^{13} \mathrm{C}$ NMR: $\delta 151.46$ (ddd, $J$ 250, 10, $4 \mathrm{~Hz}, 4 \times \mathrm{Ph}), 140.37(\mathrm{Ph}), 139.21$ (dt, J 251 Hz, $5 \mathrm{~Hz}, 2 \times \mathrm{Ph}), 135.25-135.04(\mathrm{~m}, 2 \times \mathrm{Ph})$, $130.42(2 \times \mathrm{Ph}), 125.25(\mathrm{Ph}), 118.67(2 \times \mathrm{Ph}), 113.52(\mathrm{dd}, J 16,6 \mathrm{~Hz}, 4 \times \mathrm{Ph}), \mathrm{ppm} ; \mathrm{MS}(\mathrm{EI}) \mathrm{m} / z$ : calculated value: 353.0639 , found value: $353.0637\left(\mathrm{M}^{+}\right)$; $\mathrm{mp} 92.5-93.1{ }^{\circ} \mathrm{C}$.

4-(4-Fluorophenyl)aniline (Table 6, entry 6). Prepared by procedure 4, and purified by column chromatography using petroleum ether/EtOAc 20/1 in 97\% yield. ${ }^{1} \mathrm{H}$ NMR: $\delta 7.49-7.44(\mathrm{~m}, 2 \mathrm{H}$, $\mathrm{Ph}$ ), 7.37-7.33 (m, 2H, Ph), 7.10-7.05 (m, 2H, Ph), 6.77-6.73 (m, 2H, Ph), $3.72\left(\mathrm{~s}, 2 \mathrm{H}, \mathrm{NH}_{2}\right)$, ppm; ${ }^{13} \mathrm{C}$ NMR: $\delta 161.88\left(\mathrm{~d}, J_{\mathrm{CF}}=244 \mathrm{~Hz}, \mathrm{Ph}\right), 145.85(\mathrm{Ph}), 137.35\left(\mathrm{~d}, J_{\mathrm{CCCCF}}=3 \mathrm{~Hz}, \mathrm{Ph}\right)$, $130.64(\mathrm{Ph}), 127.90(2 \times \mathrm{Ph}), 127.82(2 \times \mathrm{Ph}), 115.46\left(\mathrm{~d}, J_{\mathrm{CCF}}=21 \mathrm{~Hz}, 2 \times \mathrm{Ph}\right), 115.42(2 \times \mathrm{Ph}), \mathrm{ppm}$; MS (EI) $m / z$ : calculated value: 187.0797 , found value: $187.0795\left(\mathrm{M}^{+}\right)$; mp 120.2-121.1 ${ }^{\circ} \mathrm{C}$.

4-(3,4-Difluorophenyl)aniline (Table 6, entry 7). Prepared by procedure 4, and purified by column chromatography using petroleum ether/EtOAc 20/1 in 93\% yield. ${ }^{1} \mathrm{H}$ NMR: $\delta$ 7.32-7.28 (m, 3H, Ph), 7.23-7.13 (m, 2H, Ph), 6.76-6.73 (m, 2H, Ph), 3.76 (s, 2H, NH$)$, ppm; ${ }^{13} \mathrm{C} \mathrm{NMR:} \delta$ 150.48 (dd, $J$ 245, 13 Hz, Ph), 149.23 (dd, J 245, 13 Hz, Ph), 146.37 (Ph), 138.39 (dd, J 6, 4 Hz, $\mathrm{Ph}), 129.36(\mathrm{Ph}), 127.87(2 \times \mathrm{Ph}), 122.07$ (dd, J 6, $4 \mathrm{~Hz}, \mathrm{Ph}), 117.34$ (d, J $17 \mathrm{~Hz}, \mathrm{Ph}), 115.40$ $(2 \times \mathrm{Ph}), 115.07(\mathrm{~d}, J 17 \mathrm{~Hz}, \mathrm{Ph})$, ppm; MS (EI) $\mathrm{m} / \mathrm{z}$ : calculated value: 205.0703, found value: $205.0694\left(\mathrm{M}^{+}\right)$; $\operatorname{mp} 88.3-89.2{ }^{\circ} \mathrm{C}$. 
4-(3,4,5-Trifluorophenyl)aniline (Table 6, entry 8). Prepared by procedure 4, and purified by column chromatography using petroleum ether/EtOAc 20/1 in 92\% yield. ${ }^{1} \mathrm{H}$ NMR: $\delta$ 7.32-7.29 (m, 2H, Ph), 7.13-7.07 (m, 2H, Ph), 6.75-6.72 (m, 2H, Ph), 3.80 (s, 2H, NH ), ppm; ${ }^{13} \mathrm{C} \mathrm{NMR:} \delta$ 151.38 (ddd, $J$ 247, 10, 5 Hz, 2×Ph), $146.84(\mathrm{Ph}), 139.85-137.06$ (m, 2×Ph), $128.25(\mathrm{Ph}), 127.78$ $(2 \times \mathrm{Ph}), 115.35(2 \times \mathrm{Ph}), 109.95(\mathrm{dd}, J 16,6 \mathrm{~Hz}, 2 \times \mathrm{Ph}), \mathrm{ppm} ; \mathrm{MS}$ (EI) $m / z$ : calculated value: 223.0609, found value: $223.0599\left(\mathrm{M}^{+}\right) ; \mathrm{mp} 83.6-84.1^{\circ} \mathrm{C}$.

\section{Acknowledgements}

The authors thank the financial support from the National Natural Science Foundation of China (21076034, 20923006), the Fundamental Research Funds for the Central Universities (DUT11LK15), and the Ministry of Education (the Program for New Century Excellent Talents in University).

\section{References}

1. Langhals, H.; Ismael, R.; Yürük, O. Tetrahedron 2000, 56, 5435.

2. Li, J. J.; Wang, H.; Tino, J. A.; Robl, J. A.; Herpin, T. F.; Lawrence, R. M.; Biller, S.; Jamil, H.; Ponticiello, R.; Chen, L.; Chu, C.; Flynn, N.; Cheng, D.; Zhao, R.; Chen, B.; Schnur, D.; Obermeier, M. T.; Sasseville, V.; Padmanabha, R.; Pike, K.; Harrity, T. Bioorg. Med. Chem. Lett. 2007, 17, 3208.

3. Miura, Y.; Nishi, T. J. Org. Chem. 2005, 70, 4177.

4. Meinhard, D.; Wegner, M.; Kipiani, G.; Hearley, A.; Reuter, P.; Fischer, S.; Mart, O.; Rieger, B. J. Am. Chem. Soc. 2007, 129, 9182.

5. Zakai, U. I.; Bloch-Mechkour, A.; Jacobsen, N. E.; Abrell, L.; Lin, G.; Nichol, G. S.; Bally, T.; Glass, R. S. J. Org. Chem. 2010, 75, 8363

6. Zuideveld, M. A.; Wehrmann, P.; Röhr, C.; Mecking, S. Angew. Chem. Int. Ed. 2004, 43, 869.

7. Alexander, S. G.; Cole, M. L.; Morris, J. C. New J. Chem. 2009, 33, 720.

8. Eberhardt, R.; Allmendinger, M.; Luinstra, G. A.; Rieger, B. Organometallics 2003, 22, 211.

9. Bai, G.; Singh, S.; Roesky, H. W.; Noltemeyer, M.; Schmidt, H. J. Am. Chem. Soc. 2005, 127, 3449.

10. Lee, D.; Jin, M. Org. Lett. 2011, 13, 252.

11. Fujioka, Y.; Ozasa, S.; Sato, K.; Ibuki, E. Chem. Pharm. Bull. 1985, 33, 22.

12. Ozasa, S.; Fujioka, Y.; Kikutake, J. I.; Ibuki, E. Chem. Pharm. Bull. 1983, 31, 1572.

13. Miura, Y.; Oka, H.; Momoki, M. Synthesis 1995, 1419.

14. Basu, B.; Das, P.; Bhuiyan, M. M. H.; Jha, S. Tetrahedron Lett. 2003, 44, 3817.

15. Paul, S.; Clark, J. H. Green Chem. 2003, 5, 635. 
16. Miura, Y.; Momoki, M.; Nakatsuji, M. J. Org. Chem. 1998, 63, 1555.

17. Bolliger, J. L.; Frech, C. M. Adv. Synth. Catal. 2010, 352, 1075.

18. Azzena, U.; Cattari, M.; Melloni, G.; Pisano, L. Synthesis 2003, 2811.

19. Thiot, C.; Schmutz, M.; Wagner, A.; Mioskowski, C. Angew. Chem. Int. Ed. 2006, 45, 2868.

20. Rao, G. K.; Kumar, A.; Ahmed, J.; Singh, A. K. Chem. Commun. 2010, 46, 5954.

21. Liu, L.; Zhang, Y.; Wang, Y. J. Org. Chem. 2005, 70, 6122.

22. Miyaura, N.; Suzuki, A. Chem. Rev. 1995, 95, 2457.

23. Nakamura, I.; Yamamoto, Y. Chem. Rev. 2004, 104, 2127.

24. Ren, T. Chem. Rev. 2008, 108, 4185.

25. Torborg, C.; Beller, M. Adv. Synth. Catal. 2009, 351, 3027.

26. Polshettiwar, V.; Decottignies, A.; Len, C.; Fihri, A. ChemSusChem 2010, 3, 502.

27. Chemler, S. R.; Trauner, D.; Danishefsky, S. J. Angew. Chem. Int. Ed. 2001, 40, 4544.

28. Kotha, S.; Lahiri, K.; Kashinath, D. Tetrahedron 2002, 58, 9633.

29. Bellina, F.; Carpita, A.; Rossi, R. Synthesis 2004, 15, 2419.

30. Kotha, S.; Lahiri, K. Eur. J. Org. Chem. 2007, 1221.

31. Kitamura, Y.; Sako, S.; Tsutsui, A.; Monguchi, Y.; Maegawa, T.; Kitade, Y.; Sajiki, H. Adv. Synth. Catal. 2010, 352, 718.

32. Del Zotto, A.; Amoroso, F.; Baratta, W.; Rigo, P. Eur. J. Org. Chem. 2009, 110.

33. Liu, L.; Zhang, Y.; Xin, B. J. Org. Chem. 2006, 71, 3994.

34. Liu, C.; Yang, W. Chem. Commun. 2009, 41, 6267.

35. Han, W.; Liu, C.; Jin, Z. Adv. Synth. Catal. 2008, 350, 501.

36. Han, W.; Liu, C.; Jin, Z. Org. Lett. 2007, 9, 4005.

37. Liu, C.; Ni, Q.; Bao, F.; Qiu, J. Green. Chem. 2011, 13, 1260.

38. Liu, C.; Han, N.; Song, X.; Qiu, J. Eur. J. Org. Chem. 2010, 5548.

39. Liu, C.; Ni, Q.; Hu, P.; Qiu, J. Org. Biomol. Chem. 2011, 9, 1054. 